\title{
Malvaceae in the flora of Egypt 2. Pollen morphology and its taxonomic significance
}

\author{
Hasnaa A. Hosni \\ and \\ Sheriffa Araffa \\ The Herbarium, Faculty of Science, \\ Cairo University, Giza, 12613, Egypt.
}

Hosni A.H. \& Araffa S., 1999. Malvaceae in the flora of Egypt. 2. Pollen morphology and its taxonomic significance. Taeckholmia 19(2): 147-156.

The pollen grains of 22 species bolonging to 10 genera of Malvaceae which are represented in the flora of Egypt were studied using light microscope (LM). The pollen grains are spheroidal, relatively large with numerous pores scattered irregularly all over the grain, sculpturing is echinate. Pollen morphological differences were found useful when combined with other gross morphological characters to distinguish between certain taxa.

Key words: Flora of Egypt, Malvaceae, pollen morphology; taxonomy

\section{Introduction}

The indigenous taxa of Malvaceae in Egypt were the subject of a recent study carried out by El-Hadidi et al. (1999). A total of 25 species belonging to 11 genera are recorded, of which Malvella sherardiana is new to the flora of Egypt.

Saad (1960), gave an account of the pollen morphology of 35 indigenons and cultivated species, belonging to 17 genera of Malvaceae growing in Egypt. Keys for the identification of Hibiscus and Gossypium species based on pollen morphology were provided. He pointed out (op. cit., 1960), that generic and specific differences include variations in pollen size, shape and length of spines, nature and number of pores and relative thickness of sexine and nexine. He also stated that pollen characters confirm the affinities of morphologically and cytologically related genera.

Christensen (1986), described the pollen morphology of 120 species belonging to 40 genera of Malvaceae and compared the results with the recent classification of the family (Hutchinson, 1967) with special reference to phylogeny, cytology and the evolutionary trends in pollen morphology. He pointed out that Malvaceae seems to be an ancient family with the tribes Malveae and Abutileae as to have had a long and distinct evolutionary history while Hibisceae and Ureneae are closely allied tribes and can be regarded as the most advanced within the family. However, he admitted that the generic delimitation, based on pollen morphology is rather difficult among the studied species of the family.

Received 14 May 1999. Revision accepted 25 November 1999. 


\section{Materials and Methods}

Pollen materials belonging to 22 species and 10 genera of a total of 25 species which are native to the Flora of Egypt, are the subject of the present study. Collecting localities for the examined specimens are given in table (1).

Pollen samples, were obtained from anthers of mature, fresh flowers, or from herbarium specimens kept in Cairo University Herbarium, (CAI) and the Herbarium of Agricultural Research Centre, Flora and Phytotaxomy section (CAIM).

Polleniferous materials were boiled for about 30 seconds in an aquous 5\% $\mathrm{NaOH}$, washed several times with distilled water, spread on a clean slide in a drop of lactic acid and gently heated until the boiling point. The pollen grains were examined using a Nikon 140 Research microscope with an attatched Fx 35 photograph equipment; photopraphs are taken at magnifications ranging between x $250-1000$.

Mature undamaged pollen grains were obtained from pollen samples (2-3 samples/specimen, Table 1). Seven-ten pollen grains/slide representing a sample, were used for the measurements of the grain diameter (in $\mu \mathrm{m}$ ), apertures' number and diameter, spine characters including shape, length and density of spines. In order to quantify the density of spines, the number was scored in $16 \mathrm{~cm}^{2}$ area of 1000 magnification prints (representing actual area of $1600 \mu \mathrm{m}^{2}$ ). Pollen terminology is that of Erdtman (1963).

\section{Results and Discussion}

Microscopic examination of pollen grains of the studied species of Malvaceae showed apparent uniformity. One pollen type was recognized: pollen grains are spheroidal with tectate exine, numerous pores scattered irregularly all over the grain surface (polypantoporate); sculpturing is echinate, spines are irregularly distributed, triangular with acute - acuminate or blunt apices and pulvinous bases, each is sometimes provided with cushion at the base.

Table (2), summarizes the available information of the pollen features among the studied species. It will be noticed that the size of pollen grains varied considerably among the different taxa. It ranged between $50-140 \mu \mathrm{m}$ (spines are not included). The smallest grains are those of Malvella sherardiana, Malva neglecta and Abutilon pannosum (mean diameter $50-60 \mu \mathrm{m}$ ) the largest grains are those of Hibiscus sabdariffa and H. trionum (mean diameter $140 \mu \mathrm{m})$. The apertures are either few in number $(18-40)$ in most of the examined taxa, or numerous (up to 110) among the examined species of tribe Malveae. The apertures are narrow $(0.5-4.5 \mu \mathrm{m})$ in the species of tribes Malveae and Abutileae, wider apertures $(5-7.5 \mu \mathrm{m})$ were observed in Sida alba, Malvastrum coromandelianum and Malva nicaeensis. The apertures of Hibiscus trionum and H. vitifolius are the widest among the examined taxa being $7.5-12 \mu \mathrm{m}$ diameter and $6.5-12 \mu \mathrm{m}$ diameter respectively.

All the examined taxa possess numerous, mostly triangular irregularly distributed spines. The spines are either very crowded (more than $40 / 1600 \mu^{2}$ ) in the studied species of tribe Malveae and Sida alba or are widely spaced in the other examined species. The spines varied considerably in length at the generic and even at the specific level. The spines are relatively long $(10-25 \mu \mathrm{m})$ in the examined species of tribes Hibisceae and Ureneae; they are shorter $(0.5-10 \mu \mathrm{m})$ among the remaining species. The 
spines are dimorphic i.e. long with acute apices and short with blunt apices in the pollen grains of tribe Malveae. Spines of the examined pollen grain of the species of Abutileae are provided by basal cushions.

The exine of the examined pollen grains is generally thick $(4-10 \mu \mathrm{m})$, it is thin $(1 \mu \mathrm{m})$ in Malvella sherardiana. The sexine is as thick as nexine in the studied taxa of Malveae; it is relatively thinner in tribe Hibisceae; nexine is four times as thick as sexine in the examined pollen grains of Ureneae.

Table (2) provides useful data, for pollen morphological differences, which can be used as key characters for the distinction of certain taxa. The pollen grains of the studied species of Hibisceae are characterized by relatively large (up to $150 \mu \mathrm{m}$ diameter) pollen grains with long conical spines (up to $19 \mu \mathrm{m}$ ). Apertures are frequently with larger diameter (up to $10 \mu \mathrm{m}$ ). The pollen morphology of the examined species of Pavonia (tribe Ureneae) showed great similarity in its features with those of the species of Hibisceae. Christensen (1986), pointed out that the resemblence in pollen characters of both tribes could be explained by parallel evolution.

According to Hutchinson (1967), Abutileae comprises the subtribes Abutilinae and Sidinae. The pollen grains of the species of this tribe are readily distinguished by spines with basal cushions. The number of apertures are relatively high $(30-50)$ in subtribe Sidinae than in Abutilinae (18 - 30). This is an evidence (Christensen, op. cit.: 112) that the species of Sidinae are more advanced than those of Abutilinae. Thus, it seems appropriate, with reference to pollen morphology that the subdivision of Abutileae into Abutilinae and Sidinae is in agreement with Hutchinson (op. cit.).

Tribe Malveae is represented in Egypt by subtribe Malvinae, the size of pollen grains among the examined species varied between $60 \mu \mathrm{m}$ (mean diameter) in Malva neglecta to $137 \mu \mathrm{m}$ (mean diameter) in Alcea striata. The number of apertures is the highest among the examined Egyptian taxa; it ranged between 50 - 116 / grain.

Species of Malveae also differs from those belonging to the other tribes in having crowded dimorphic spines: long $(1.7-12 \mu \mathrm{m})$ with acute apices and short $(0.5-7 \mu \mathrm{m})$ with blunt apices. The length of spines was found useful as a key character for the separation between the studied species of Malva.

In conclusion, the pollen morphology of the species of Malvaceae in Egypt suggests that some features can be useful in assessing taxonomic relationships between the studied species. These include the diameter of pollen grains, number and diameter of apertures as well as the shape and length of spines.

These features were found useful, when combined with other macromorphological characters (e.g. bracteoles, fruit and floral characters) to distinguish between certain taxa. This is for instance the case of Althaea which differs from Alcea regards the number of mericarps, the pollen grain size and the number of pores. The number of mericarps is less $(8-10)$ in Althaea than in Alcea (20). The pollen grains are smaller in Althaea (mean diameter $82 \mu \mathrm{m}$ ) with a larger number of pores $(60-70)$. These are larger in Alcea (mean diameter $137 \mu \mathrm{m}$ ) with fewer number of pores $(50-60)$. 
Table (1): Specimens investigated.

\begin{tabular}{|c|c|}
\hline Taxa & Localities \\
\hline Hibiscus trionum & $\begin{array}{l}\text { El Fayium, Ibshwai, 5.11.1985; Abdel Ghani } 4288 \text { (CAI) - Baltim, 13.7.1977; Abdel } \\
\text { Maqsud s.n. (CAI) - Ganzour, Menoufia, 15.9.1967; V. Täckhnolm et al. s.n. (CAI). }\end{array}$ \\
\hline H. micranthus & $\begin{array}{l}\text { Elba district, Gebel Gogart, 7.2.1962; V. Täckholm et al. } 1782 \text { (CAI) - Wadi } \\
\text { kansisrob, Elba, 3.2.1962; V. Täckholm } 1290 \text { (CAI). }\end{array}$ \\
\hline H. vitifolius & $\begin{array}{l}\text { Elba, Wadi Kansisrob, 23-27.1.1929; G. Täckholm s.n. (CAI) - Across Gebel El } \\
\text { shallal, Elba, 24.1.1962; V. Täckholm et al. } 550 \text { (CAI). }\end{array}$ \\
\hline H. sabdariffa & $\begin{array}{l}\text { Faculty of science garden, Giza, 5.11.1991; S. Araffa s.n. (CAI) - North garden, El } \\
\text { Saff, 27.10.1961; V. Täckholm s.n. (CAI). }\end{array}$ \\
\hline Abutilon theophrasti & $\begin{array}{l}3 \mathrm{~km} \text { S of Tanta, 11.9.1991; S. Araffa s.n. (CAI) - San El Hagar, Sharkiya, } \\
\text { 10.8.1983; Amer et al. } 4557 \text { (CAI) - Bircher's garden, El Saff, 14.11.1961; V. } \\
\text { Täckholm et al. s.n. (CAI). }\end{array}$ \\
\hline A. bidentatum & $\begin{array}{l}\text { Wadi Angabiya, Suez road, 28.1.1956; Imam s.n. (CAI) - El Dakhla Oasis, Ain } \\
\text { Fatima, 9.6.1961; V. Täckholm et al. s.n. (CAI). }\end{array}$ \\
\hline A. fruticosum & $\begin{array}{l}\text { Gebel Elba, 7.2.1962; V. Täckholm s.n. (CAI) - Gebel Hamata, Red Sea Coast, } \\
\text { 7.2.1961; V. Täckholm et al. s.n. (CAI). }\end{array}$ \\
\hline A. pannosum & $\begin{array}{l}\text { Abu Simbel, 14.2.1963; V. Täckholm et al. s.n. (CAI) - Kharga Oasis, Doush } \\
\text { village, 24.11.1983; Barakat s.n. (CAI). }\end{array}$ \\
\hline A. figarianum & Wadi Ghweibba, RSC, 9.6.1960; V. Täckholm et al. s.n. (CAI). \\
\hline Sida alba & $\begin{array}{l}\text { Bahr El Ezz, El Mansoura, 27.10.1967; V. Täckholm et al. s.n. (CAI) - Sinnuris, } \\
\text { Fayium, 23.3.1991; S. Araffa s.n. (CAI) - Beni Suef, 1.7.1952; Boulos s.n. (CAI). }\end{array}$ \\
\hline Malvella sherardiana & Dakhla Oasis, 6.3.1934; Shabetai Z 4363 (CAIM). \\
\hline $\begin{array}{l}\text { Malvastrum } \\
\text { Coromandelianum }\end{array}$ & $\begin{array}{l}\text { El Saff, 15.5.1971; Bircher s.n. (CAI). Zohria Garden, 15.5.1927; G. Täckholm s.n. } \\
\text { (CAI). }\end{array}$ \\
\hline Malva aegyptia & $\begin{array}{l}\text { Burg El Arab, 20.3.1953; El Hadidi s.n. (CAI) - El Daba, 16.3.1991; S. Araffa s.n. } \\
\text { (CAI) - N of El Arish, 18.3.1955; El Hadidi s.n. (CAI). }\end{array}$ \\
\hline M. parviflora & $\begin{array}{l}\text { Saqqara fields, 15.3.1992; S. Araffa s.n. (CAI) - El Amriya, 7.3.1991; S. Araffa s.n. } \\
\text { (CAI) - Itsa, El Fayium, 9.3.1983; Abdel Ghani } 5664 \text { (CAI). }\end{array}$ \\
\hline M. nicaeensis & $\begin{array}{l}\text { Burg El Arab, 1.4.1952; Bot. Dept. Excurs. s.n. (CAI) - Burg El Arab, 25.1.1978; } \\
\text { Abdel Wahab s.n. (CAI). }\end{array}$ \\
\hline M. neglecta & $\begin{array}{l}\text { Deir El Arbaeen, Sinai, 7.5.1980; Abbas s.n. (CAI) - The graden of st. Katherine, } \\
\text { 11.4.1967; Kosinova' s.n. (CAI). }\end{array}$ \\
\hline M. sylvestris & $\begin{array}{l}\text { Mersa Matrouh, 1.4.1972; V. Täckholm et al. s.n. (CAI) - Maruit, Amriya, } \\
\text { 14.3.1991; S. Araffa s.n. (CAI) - Ismailia, 18.3.1927; G. Täckholm s.n. (CAI). }\end{array}$ \\
\hline Althaea ludwigii & $\begin{array}{l}\text { Cairo - Suez road, 15.1.1960; V. Täckholm s.n. (CAI) - N Galala, 11.4.1924; } \\
\text { Simpson } 2743 \text { (CAIM). }\end{array}$ \\
\hline Alcea striata & Deir El Arbain, Sinai, 12.5.1956; El Hadidi s.n. (CAI). \\
\hline Lavatera cretica & $\begin{array}{l}\text { Rosetta, 20.4.1973, Ibrahim et al. s.n. (CAI) - Burg El Arab, 22.3.1956; El Hadidi } \\
\text { s.n. (CAI). }\end{array}$ \\
\hline Pavonia kotschyi & Wadi Kansisrob, G. Elba, 25.1.1929; Shabetai 2677 (CAIM). \\
\hline P. triloba & $\begin{array}{l}\text { Gebel Elba, 13.2.1932; Drar } 334 \text { (CAIM) - Karam Elba mountain, 7.2.1962; V. } \\
\text { Täckholm et al. } 1720 \text { (CAI). }\end{array}$ \\
\hline
\end{tabular}


Table (2): Pollen morphology of examined species of Malvaceae.

\begin{tabular}{|c|c|c|c|c|c|}
\hline \multirow[b]{2}{*}{ Species } & \multirow{2}{*}{$\begin{array}{c}\text { Diameter of } \\
\text { Pollen } \mu \mathrm{m} \\
\text { (mean in } \\
\text { brackets) }\end{array}$} & \multicolumn{2}{|c|}{ Aperture } & \multicolumn{2}{|l|}{ Spine } \\
\hline & & Number & $\begin{array}{l}\text { Diam. } \mu \mathrm{m} \\
\text { (mean in } \\
\text { brackets) }\end{array}$ & $\begin{array}{l}\text { Length } \mu \mathrm{m} \\
\text { (mean in } \\
\text { brackets) }\end{array}$ & $\begin{array}{c}\text { No. of } \\
\text { spines / } \\
1600 \mu \mathrm{m}\end{array}$ \\
\hline Hibisceae: & & & & & \\
\hline Hibiscus trionum & $110-150(130)$ & $20-25$ & $7.5-12(10)$ & $10-18(14)$ & $4-5$ \\
\hline H. micranthus & $70-100(85)$ & $20-24$ & $6.5-7.5(7)$ & $10-19(15)$ & $5-6$ \\
\hline H. vitifolius & $120-150(135)$ & $30-36$ & $6.5-12(9)$ & $12-18(15)$ & 10 \\
\hline H. sabdariffa & $120-160(140)$ & $20-26$ & $7-9(8)$ & $11.5-18(14.8)$ & $8-10$ \\
\hline Abutileae-Abutilinae & & & & & \\
\hline Abutilon theophrasti & $46-75(60)$ & $18-20$ & $1.5-2.5(2)$ & $6.5-7.5(7)$ & $14-15$ \\
\hline A. bidentatum & $63-75(69)$ & $24-30$ & $0.5-1.5(1)$ & $0.5-1(0.8)$ & $24-25$ \\
\hline A. fruticosum & $62-87(75)$ & $20-30$ & $0.5-3(1.8)$ & $3-6.5(4.8)$ & $20-22$ \\
\hline A. pannosum & $50-65(55)$ & $22-30$ & $1-2.5(1.8)$ & $4-6(5)$ & $22-23$ \\
\hline A. figarianum & $60-80(70)$ & $20-24$ & $1.5-4.5(3)$ & $3-6.5(4.5)$ & $13-14$ \\
\hline Abutileae - Sidinae & & & & & \\
\hline Sida alba & $60-80(70)$ & $44-50$ & $4.5-6.5(5.5)$ & $3-10(6)$ & $56-64$ \\
\hline Malvella sherardiana & $40-60(50)$ & $30-35$ & $0.5-1.5(1)$ & $3-6(4)$ & $15-16$ \\
\hline Malvastrum coroman- & $69-87(78)$ & $25-30$ & $6.3-7.5(6.9)$ & $6.3-8(7)$ & $18-20$ \\
\hline delianum & & & & & \\
\hline Malveae & & & & & \\
\hline Malva aegyptia & $81-106(94)$ & $80-90$ & $0.5-1.5(1)$ & $7-10(8.5)$ & $40-47$ \\
\hline M. parviflora & $70-80(75)$ & $110-115$ & $3-5(4)$ & $0.2-1.7(1.1)$ & $60-62$ \\
\hline M. nicaeensis & $60-80(70)$ & $100-105$ & $5-7(6)$ & $3-12(7.5)$ & $35-40$ \\
\hline M neglecta & $45-60(50)$ & $100-110$ & $0.5-2(1.3)$ & $1.5-3(2.3)$ & $12-15$ \\
\hline M. sylvestris & $44-112(103)$ & $90-100$ & $0.5-2(1.3)$ & $3-12(7.5)$ & $40-45$ \\
\hline Althaea ludwigii & $65-100(82)$ & $60-70$ & $1.5-5(3.3)$ & $3-9(6)$ & $58-60$ \\
\hline Alcea striata & $119-156$ (137) & $50-60$ & $1.5-3(2.3)$ & $3-9.9(6.2)$ & $30-32$ \\
\hline Lavatera cretica & $100-140(122)$ & $2-4.5$ & $2-4.5(2.3)$ & $3-8(5.5)$ & $60-70$ \\
\hline Ureneae & & & & & \\
\hline Pavonia kotschyi & $61-94(77)$ & $24-30$ & $3-6.5(4.8)$ & $10-25(17.5)$ & $4-5$ \\
\hline P. triloba & $110-135(130)$ & $30-40$ & $6.5-7.5(7)$ & $12-15(13.5)$ & $13-15$ \\
\hline
\end{tabular}

The following key is constructed to distinguish between the studied species. It combines both of gross - morphologic and palynological characters.

1. a. Style branches and stigmas the same number as the carpels, or style undivided; spines of exine $0.5-19 \mu \mathrm{m}$ long

b. Style branches and stigmas twice the number of the carpels; spines of exine $13-25 \mu \mathrm{m}$ long (tribe Ureneae)

aruit a loculicidal capsule; spines of exine $10-19 \mu \mathrm{m}$ long (tribe Hibisceae) 
b. Fruit schizocarpic; spines of exine $0.5-10 \mu \mathrm{m}$ long (tribe Malveae and Abutileae)

3. a. Bracteoles (epicalyx) 3, broadly ovate - cordate, apically toothed, styles undivided

Gossypium arboreum

b. Bracteoles (epicalyx) numerous, filiform - linear, entire; styles divided

4. a. Fruit ovoid not included in calyx; pollen grains less than $100 \mu \mathrm{m}$ diameter

Hibiscus micranthus

b. Fruit included in persistent calyx; pollen grains more than $100 \mu \mathrm{m}$ diameter

5. a. Epicalyx segments linear - lanceolate; seeds hispid

Hibiscus sabdariffa

b. Epicalyx segments filiform; seeds tuberculate

6. a. Fruit spheroidal, $1 \mathrm{~cm}$ diameter, beaked and winged; pollen grains with crowded spines $\left(10 / 1600 \mu \mathrm{m}^{2}\right)$

b. Fruit oblong - ovoid, $1.5 \times 1 \mathrm{~cm}$, obtuse, wingless; pollen grains with sparsely spaced spines $\left(4-5 / 1600 \mu \mathrm{m}^{2}\right)$

Hibiscus vitifolius Stigmas decurrent on the style branches; spines of exine dimorphic without a basal cushion (Tribe Malveae)

b. Stigmas apical, capitate, larger than the remainder of the style branches; spines of exine homomorphic with basal cushions (Tribe Abutileae) .....

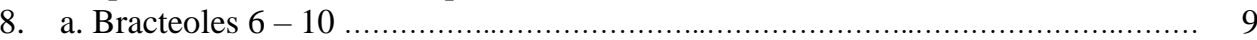

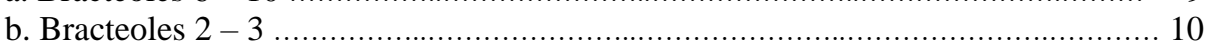

9. a. Mericarps more than 20; pollen grains more than $100 \mu \mathrm{m}$ diameter, number of aperture less than 60

Alcea striata

b. Mericarps ca. 10; pollen grains less than $100 \mu \mathrm{m}$ diameter, number of apertures more than 60

Althaea ludwigii

10. a. Bracteoles connate at base ................................................... Lavatera cretica

b. Bracteoles free ......................................................................... 11

11. a. Epicalyx of 2 bracteoles ........................................... Malva aegyptia

b. Epicalyx of 3 bracteoles ..................................................................... 12

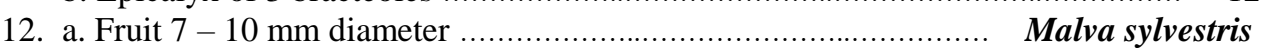

b. Fruit up to $7 \mathrm{~mm}$ diameter ...................................................... 13

13. a. Bracteoles linear; mericarps with elevated margins ................ Malva parviflora

b. Bracteoles elliptic, ovate or oblong; mericarps without elevated margins ......... 14

14. a. Mericarps smooth on the dorsal surface; spines of exine $1.5-3 \mu \mathrm{m}$ long, diameter of aperture $0.5-2 \mu \mathrm{m}$

Malva neglecta

b. Mericarps deeply reticulate on the dorsal surface; spines of exine 7-12 $\mu \mathrm{m}$ long, diameter of aperture $6 \mu \mathrm{m}$

Malva nicaeensis

15. a. Bracteoles absent; mericarps \pm dehiscent into two valves ......................... 16

b. Bracteoles present; mericarps indehiscent .................................... 21

16. a. Mericarps one - seeded; pollen grains ca. $90 \mu \mathrm{m}$ diameter, number of apertures more than 30, aperture diameter over $3 \mu \mathrm{m}$

Sida alba

b. Mericarps 2 - 3 -seeded; pollen grains $55-85 \mu$ m diameter, number of

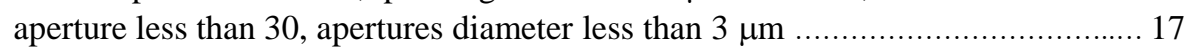

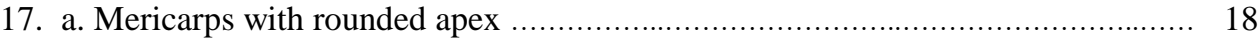


b. Mericarps with acute - acuminate apex

18. a. Petals $10-25 \mathrm{~mm}$ long, yellow with purple base; spines of exine 4-5 $\mu \mathrm{m}$ long

b. Petals $7-9 \mathrm{~mm}$ long, yellow without purple base; spines of exine 6-7 $\mu \mathrm{m}$ long Abutilon figarianum

19. a. Mericarp 2 - awned Abutilon theophrasti

b. Mericarp not awned with acute - acuminate apex

20. a. Mericarps 10; fruit $12 \mathrm{~mm}$ diameter, spines of exine 3-6.5 $\mu \mathrm{m}$ long Abutilon fruticosum

b. Mericarps 20; fruit $7 \mathrm{~mm}$ diameter, spines of exine $0.5-1 \mu \mathrm{m}$ long

Abutilon bidentatum

21. a. Mericarps inflated; spines of exine $0.5-1.5 \mu \mathrm{m}$ long Malvella sherardiana

b. Mericarps not inflated; spines of exine $6.5-8 \mu \mathrm{m}$ long

\section{Malvastrum Coromandelianum}

22. a. Fruit glabrous; mericarps broadly winged; pollen grains less than $100 \mu \mathrm{m}$ diameter, number of aperture less than 30

Pavonia kotschyi

b. Fruit pubescent; mericarps wingless or narrowly winged; pollen grains over $100 \mu \mathrm{m}$ diameter, number of aperture more than 30

Pavonia triloba

\section{Acknowledgements}

The authors are indebted to Prof. Dr. M. N. El Hadidi, The Herbarium, Cairo University who kindly read through the manuscript. Thanks are also due to Dr. Nahed M. Waly, for photographic aid.

\section{References}

Bentham, G. \& Hooker, K. 1862. Genera Plantarum 1: 195-209. London.

Boulos, L. 1995. Flora of Egypt, Checklist: 91-93, Al Hadara Publishing, Cairo.

Bremer, K., Bremer, B. \& Thulin, M. 1998. Introduction to phylogeny and systematics of flowering plants: 66 - 68. Dept. of systematic Botany, Uppsala University.

Christensen, P. B. 1986. Pollen morphological studies in the Malvaceae - Grana 25: 95 - 117.

EL Hadidi, M. N. \& Fayed, A. A. 1994/95. Materials for Excursion flora of Egypt. Taeckholmia 15: 96-98.

; Hosni, H. A.; El Hadidy, A. M. \& Araffa, S. A. 1999. The family Malvaceae in the flora of Egypt. 1 Systematic revision of the indigenous taxa. Taeckholmia 19(2): $147-156$.

Erdtman, G. 1963. Pollen morphology and plant taxonomy - Angiosperms. Stockholm.

Hutchinson, I. 1967. Genera of Flowering Plants 2: 536-567 - London.

Hutchinson, I. B. 1969. Evolution and Phylogeny of Flowering Plants 253-257. London.

Saad, S. I. 1960. The sporoderm stratification in the Malvaceae - Pollen \& Spores 2: $13-41$.

Schumann, K. 1895. Malvaceae in A. Engler \& K. Prantl Natulichen-Pflanzenfamilien 3(6): 30-35. Leipzig. Cobenhagen.

Täckholm, V. 1974. Students' Flora of Egypt ed. 2: 348-356 Cairo University. 

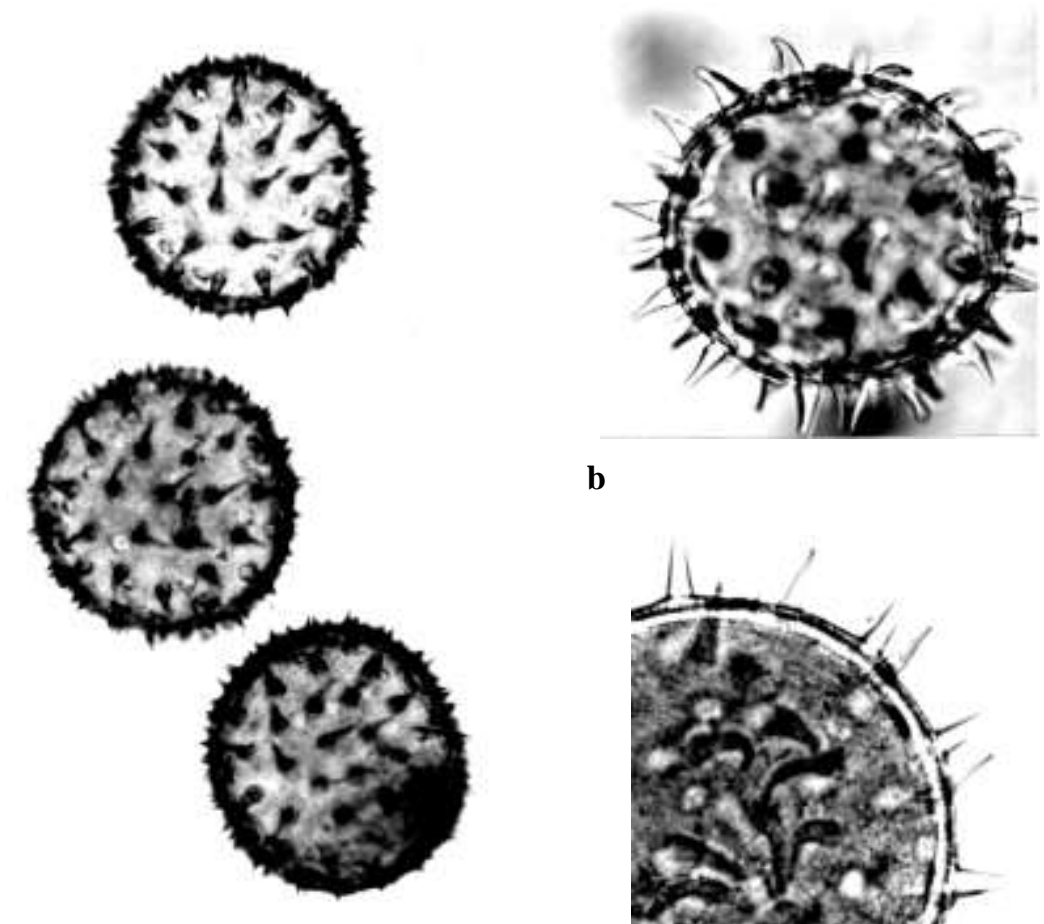

b

a

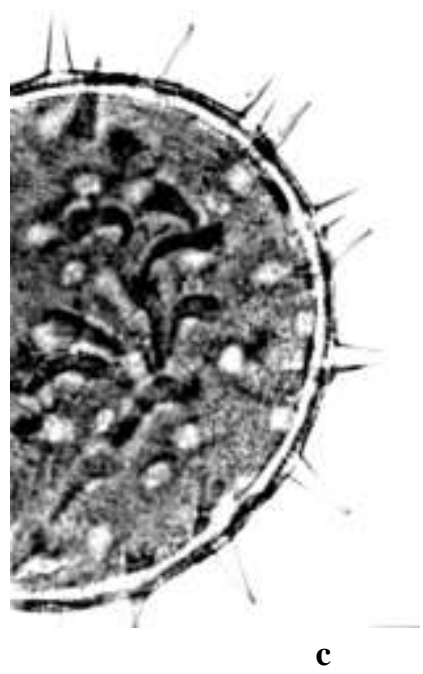

Fig. (1). Pollen morphology of representative species of Hibisceae:

a. Hibiscus trionum, x250. b. Hibiscus micranthus, $\mathrm{x} 1000$

c. Hibiscus vitifolius, $\mathrm{x} 1000$

Pollen grains large with few wide apertures and long, conical, widely spaced spines. 

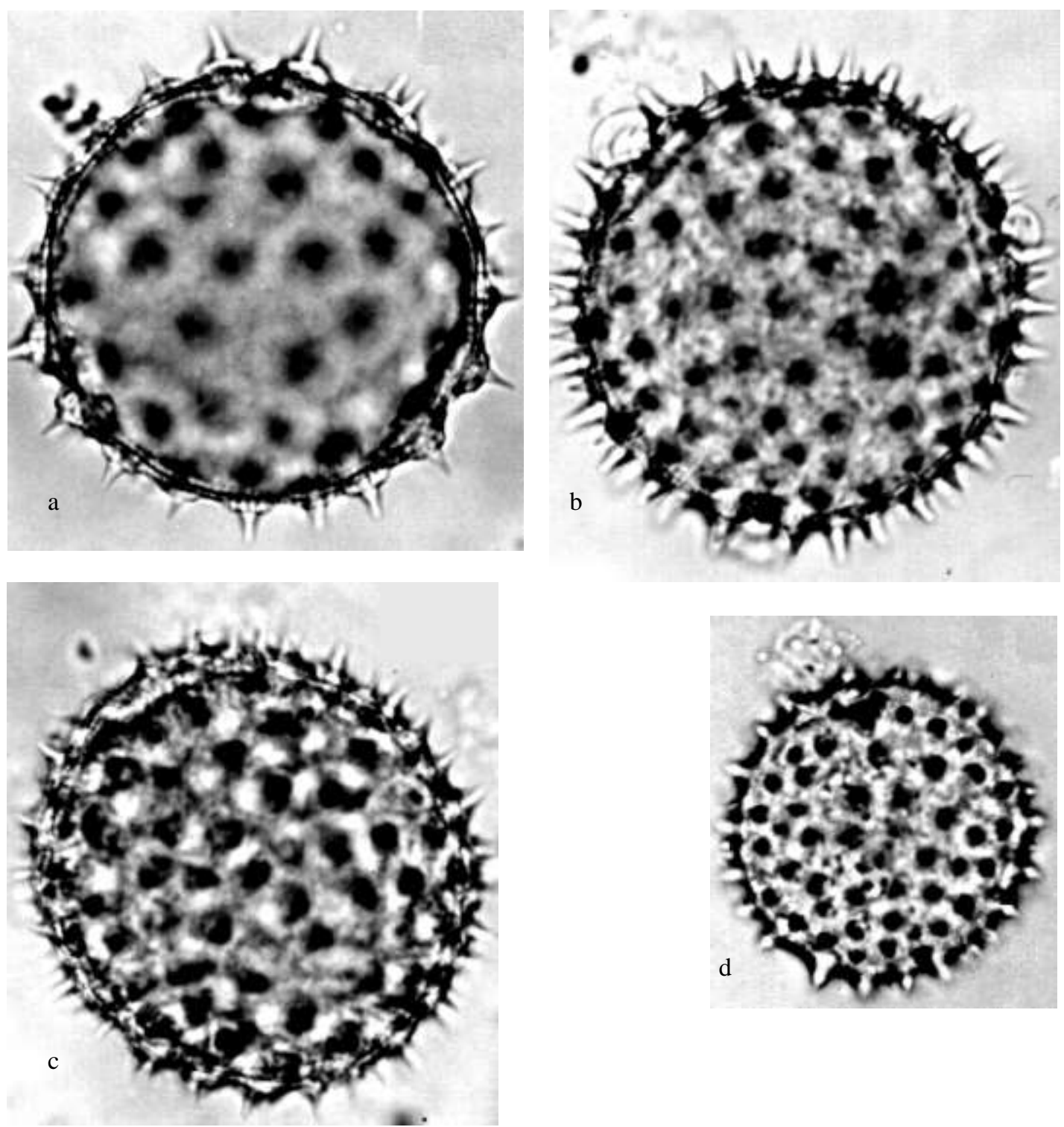

Fig. (2). Pollen morphology of representative species of Abutileae (all x1000):

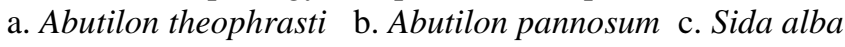

d. Malvella sherardiana

Pollen grains small, with few (Abutilon) or numerous (Sida, Malvella) apertures and short crowded spines with basal cushions. 

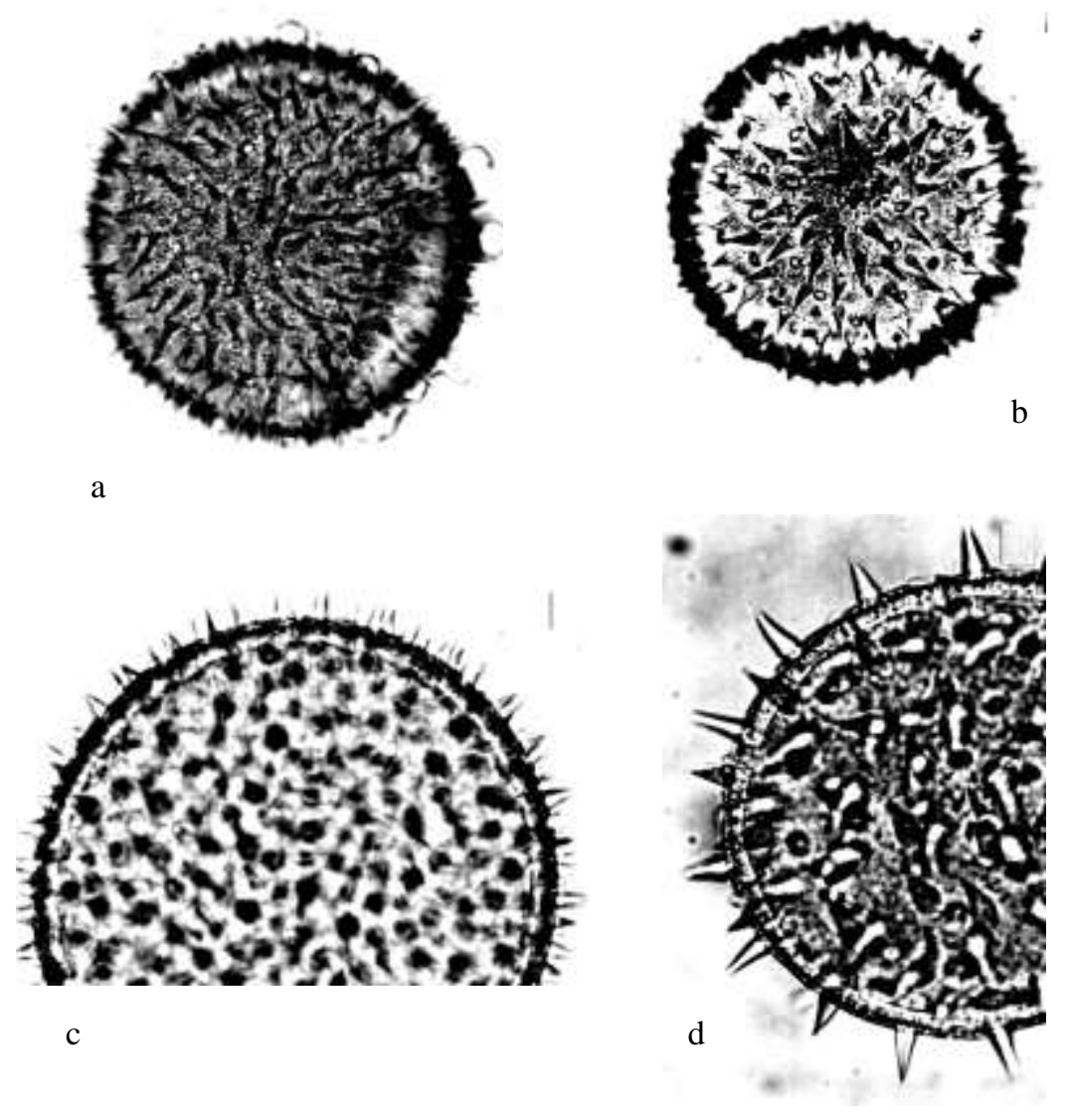

Fig. (3). Pollen morphology of representative species of Malveae and Ureneae: a. Malva aegyptia, x1000. b. Malva parviflora, x1000 $\quad$ c. Lavatera cretica, x500 c. Pavonia trioba, x500

Pollen grains large (Lavatera, Pavonia), with few wide apertures, or moderate (Malva) with numerous narrow apertures; and short crowded spines (Malva, Lavatera) or widely spaced (Pavonia) spines. 